\title{
辻・南木・小池論文に対する論評
}

\section{Comments on Tsuji, Minaki and KoIke's Paper}

$$
\text { 中 村 純 }
$$

\section{稲花粉の動態}

最近は農耕とくに稲作の歴史を花粉分析学的に解明し 上らとする試みが各地で行われている．花粉分析法は花 粉化石から過去の情報を引出す方法であり，現代生物学 その他の自然科学を背景にもった古生物の範ちゅうに属 する.したがってこの研究法の原則は「現在は過去への 鍵」といらことに Lyell 以来変らぬところである.し たがって過去の稲作を花粉によって復元しょうとする 際, 現在の稲作と花粉との関係をすず解明することか ら，この問題に取組むべきであうう，幸い稲作はわれわ れに最も親しい農耕の一種であり，その実体に接するこ とも比較的容易である.

筆者は 1977 年以来稲作にともなら稲花粉の動態, 例 えば稲花粉の生産量, 散布量, 水田に於ける稲花粉の頻 度, 水田中での花粉の移動, 残存率, 水田堆積物之湖沼 堆積物との比較などについて報告した。

今回はその概容と乞の後兄られたこの種の基礎資料に ついて報告したい.これらの資料は数少ない実例を示し たにすぎず，さらに多数の資料を集積してゆくことが望 ましいことである。

\section{1. 稻花粉の生産量}

一花京たりの花粉粒数は平均 8,000 粒である.これ をるとに概算すると水田に打ける一株あたり 2,400 万 粒, 水田 $1 \mathrm{~m}^{2}$ 当りでは 55,200 万粒が生産される勘定 になる。

\section{2. 散布量}

上の生産量のなかで粐殸内に一花めたり約 2,000 粒 残留するので，これを別にすると一株あたり 1,800 万 粒, 水田 $1 \mathrm{~m}^{2}$ あたりでは 41,400 万粒が散布されるこ とになる.この花粉はどの様な割合で水田の内外飞散布 されるであろらか.

\section{3. 散布範囲}

図 1 は 1982 年 9 月から 10 月にかけて松山市内の水 田地带で, 水田内の表土に落下した稲花粉の粒数と水田 から $10 \mathrm{~m}$ はなれた地面から $5 \mathrm{~m}$ 上空に沶かれたジャ ーレーに落下した稲花粉粒数（何れも $1 \mathrm{~cm}^{2}$ あたり）を 示したものである.な和 9 月 6 日は稲の開花日であり， 9 月 27 日は台風 8 号の影響が現れている. 稻の開花日
には株むとに 749.7 粒 $\left(1 \mathrm{~cm}^{2}\right.$ 当り) 落下し最子多い が, 比較的多いのは開花日から 2 3 日間で, 他はきわ めて少ない。

これに対して空中花粉は開花日といえども少量で, 開 花後 1 週間もすると汪とんど飛来しなくなる.このこと は花粉分析結果浑来花粉の影響はきわめて少ないこと を示唆している.また稲わらに付着した量も測定された が稲刈り時でも平均 $19,903.7$ 粒（1本あたり）に達し， 稲わらによる二次的散布は決して無視できないことが推 測された. 籾殸内に残留する花粉の二次的散布も同様に 無視でき双量に達するであるう.わが国の稲作の初期に は穂刈りが専らで, 稲わらは水田に残されたと考兄られ ている.このよらな時代の水田には稲わらに付着した分 だけ多くの稲花粉が検出される勘定になる。また皮田内 で稲の脱殼調製まで行う場合は異常に高率に稲花粉が現 れることは往々経験されるところである.

このよう散布された花粉は水田内でどの位い残存す るであろらか。

\section{4. 残存率}

からて筆者らは田植直前の水田に外来花粉つら ( Liquidambat）を一定量散布し，稲刈後残存した花粉を調 査した。 その時の残存率は $1.22 \%$ であった。これは散

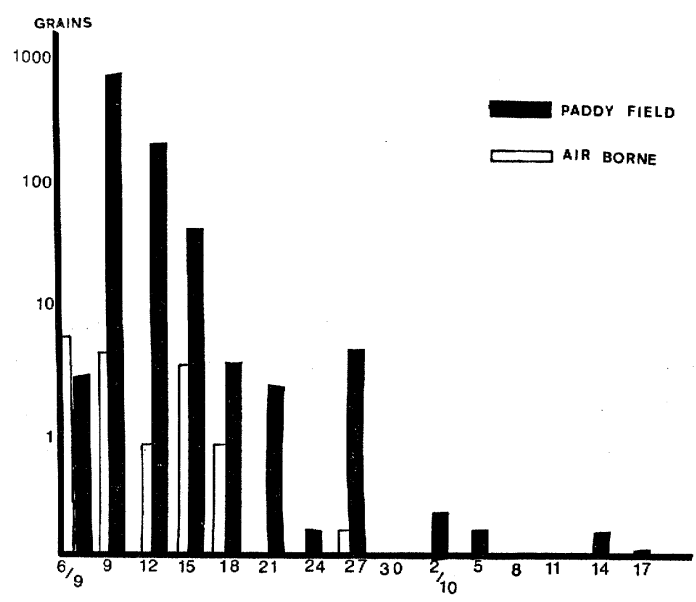

図 1 稻花粉の水田, 空中への散布粒数（グラム当り） 
布してから 6 カ月後の值であり，さらに年月がたてば残 存率が低下することは十分に考兄られることである. 高 知市内で 5 年前に無機質土境を客土した水田の表層土中 の稲花粉量を求めると平均 125 粒（ $\mathrm{g}$ 当り）であった. またこれに隣接する開田後 100 年以上を経た水田表土 の稲花粉は平均 3,455 粒（ $\mathrm{g}$ 当り）で稲花粉比率（稲花 粉が全イネ科花粉に占める割合）は $28.9 \%$ であった。 これらの数值を使って堆積速度を無視して単純計算する と, この新しい水田内の稲花粉が古い水田な奴になるに は 138 年かかることになる.さき筆者らは一般水田 表土のイネ花粉比率は約 30\% 以上となることを明ら かにしたが，残存率がきわめて低いことと合わせ考兄る
と，いかに集約栽培が行われても第一年目からこのよう な比率は得られず, この場合は 138 年以上を要するこ とになる。

以上は稲作の花粉分析的研究に必要な二, 三の基礎的 知見を述べたものであるが，他の化石を使った解明でも 同様な態度が必要と考学られよう。

\section{引用交献}

鈴木功夫 ·中村 純 (1977) 稲科花粉の堆積に関する基 礎的研究. 交部省科学研究費特定研究「古交化財」稲 作の起源と伝播に関する花粉分析学的研究（中間報 告). p. $1-10$.

(高知大学名誉教授)

\section{SK-46 地点におけるプラント・オパール分析の概要}

藤 原宏 志

Hiroshi Fujrwara

本年 5 月末, 小池裕子氏より, 上記論文へのコメント を求められ, 辻誠一郎氏から SK-46 地点の土壌試料 が送付されたのは 6 月 16 日であった。原稿の締切まで 短時日しかなく急拠分析を行ったため，充分な検討がで きたとはいえないが，とりあえず，以下の分析結果を添 竞コメントに換えたい。

\section{1. 試 料}

1983 年 6 月 16 日, 辻氏より送付された SK-46 地点 柱状土壤試料で, 表層から $85 \mathrm{~cm}$ までの層とXII層は欠 除していた。供試試料は各層のほぼ中央部を $2 \mathrm{~cm}$ 厚で 切り出したものである.

\section{2. 分析法}

プラント・オパール分析法（定量分析ガラス・ビーズ 法）に拠った．ただし，試料の仮比重データが得られな かったので, 分析結果は試料 $1 \mathrm{~g}$ に含まれるプラント. オパールの数で示すにとどめ, 生産量の復元は行わなか った。

\section{3. 分析結果}

分析結果は図 1 亿示した。

(1)イネ機動細胞プラント・オパールは XIV 層以上の 各層から検出された. XI層から XIII 層にか流てイネ機 動細胞プラント・オパールのピークが認められ，この土 層が堆積した時代にこの地で稲作が行われた可能性が高 いことを示している. XIV ですイネ機動細胞プラント. オパールが検出されたが量的に少ない，XIII 層にはい わゆる Moro ash が挾まれて扰り，同層分析試料はとの 直下土壤である. XV 層では, イネに由来するプラン
ト・オパールは検出されなかった。

(2)各層ともタケ亜科泊由来するプラント・オパールが 大量に検出された。 とくに XIV 層以下では乞の傾向が 顕著である。

(3)ヨシはX層より上層から検出されたが，量的には少 なかった。

\section{4. 考 察}

(1)辻氏等は SK-36 地点に打汸る植物遺体のデータか ら, この地で 2, 200 年以前に稲作が行われたと推定し ている. SK-46 地点は SK-36 地点と同じ茂吕の沢に位 置し, SK-36 地点より約 $1 \mathrm{~km}$ 東南の.上流部沈たる. SK-46 地点では絶対年代を推定するデータはいわゆる

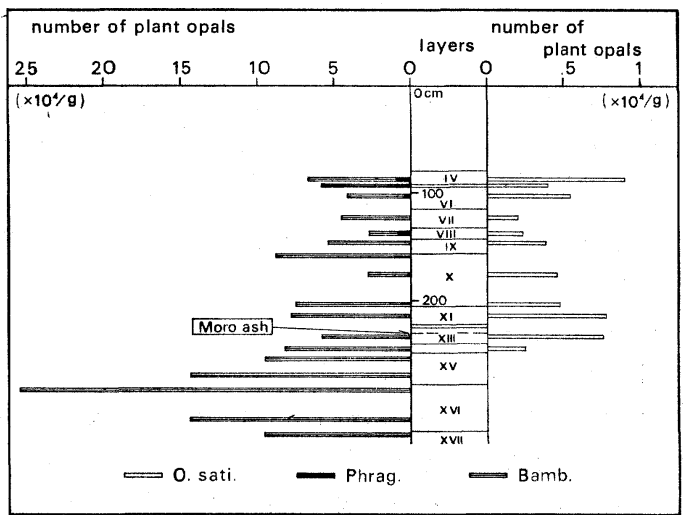

図 1 SK-46 地点におけるプラント・オパール分析 結果（試料は过による） 
Moro ash だけである. 同火山灰が $1910 \pm 140$ y. B. P. とすると，少なくとも，その時代直前にこの地で稲作が 行われていたことは確かであろら。さらに，Moro ash を包含するXIII 層より下層 (XIV) でイネ機動細胞プ ラント・オパールが検出されているが，量的にやや少な く, 両試料の垂直距離が約 $12 \mathrm{~cm}$ であることを考觉る と XIII 層からの落ち込みの可能性がある.

私たちが，考古学的資料と環境復元資料とを関連づけ て考吅時に注意しなければならない点がいくつか存在 する. その第 1 点は，両資料の間に相互関係が喼められ るほど正確な資料であるかどらかといらこと，第 2 点 は, 両者の研究にともに精通した研究者が果して存在す るのかといらこと，そして第 3 点に両者の研究資料をと もに提供する良好な遺跡がどれほど沢山あるかといらこ となどである、私どもの論議は，これらの問題点を多少 とも無視しなければ，先へ進めることができないこと

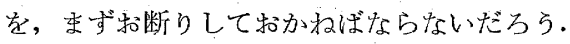

さて，この論文には考古学の立場からすると 2 つの問 題点が含まれている. ひとつは, 関東平野に和ける照葉 樹林化の打くれで，それは縄文時代後期からみられると いらことである. 他のひとつは ${ }^{14} \mathrm{C}$ 年代で， 2,300 年前 とされる層からイネの種子と花粉が発見されたという点 である・まず前者の問題をとりあげてみよう。西日本に 扣いては，縄文時代前期には照葉樹林化が開始したこと が知られているが，考古学的な文化要素のあるものはこ のような照葉樹林化の進展とは関係せずに東日本で成立 し，西日本へと流布した可能性のあるものが認められ る.

たとえば, 石器群の組織化, 集落の成立といった事例 は, 東北日本に和いて早期後半から前期にかけて確立 し，関東・中部をへて西日本へと伝わっていくといら形 で把觉ることができる. 早期に普遍的であった刃部磨製 踏斧分頭部をも丁寧に作出する磨製石杀へと変化する事 象の背景には, 森林資源に働きかけた主要な道具が確立 していったことを知ることがでさる，とのような成立が 西日本と同時期か，もしくはさらに遡ぼった時期に東日 本で扣こなわれたのであった，そこには照葉樹林化とは 無関係に生れた森林開発用具が存在するのである.

また, 現在末での資料による限り, 東北地方に見られ る大型住居は, 堅果類の調理にかかわる施設であると想 定され，縄文時代の前期から見られるのが一般的であ
(2)ここに示したプラント・オパール分析結果は，过氏 より送付された試料を急ざ分析したものであり，供試間 隔も粗く充分なものとはいえない。この地域に関する新 たな調査も計画されて扣り，試料採取の機会もあるよう なので，その際，あらためて検討することにしたい。

(宮崎大学農学部)

\section{加藤 晋 平·山田昌 久 \\ Shinpei Kato and Masahisa Yamada}

る.つづく中期を中心として認められる複式炉も東日本 一円に拡がって存在する.このような植物資源にかかわ る生活技術が，照葉樹林化とは関係せずに発生したこと は注意しなければならない。

「照葉樹林文化」論の提出は, 微視的にものを見てし まいがらな考古学者にとって, 確かに魅力的な仮説とし て出現したのであるが，日本列島に繰りひろげられた縄 文文化の文化諸要素の検討によれば，単純な図式を示す 訳にはいかないのである. 今後考古学的には「照葉樹林 文化」の指標となる大陸からの道具類がぞのように移入 されたかを具体的に把える必要があり，一方環境復元の 面からは本論文の報告者のごとく山地域每の植生復元を 綿密に日本各地で和こなっていかねばならないだろら。 それは, 日本列島全体というようなグローバルな植生復 元ではなく, 空間的にも, 時間的にもさらに一層キメ細 かなスケールのものものが要求されるだろう. 報告者の 指摘する中部・南部関東平野に招ける照葉樹林化の打く れといらような事実からみても，「照葉樹林文化」論を生 すめるためには, 今後考古学・環境復元の両面からさら に一層微視的な見方を必要とすることを本論文は教えて くれている.

ただここで問題になるのは，照葉樹林化のおくれが， 関東ローム層といら土壤の性質によるものであるとする 点である.ナラ類の多いといら暖帯落葉樹林に変ってど のようにして照葉樹林化がはじまったかという植物社会 学的な分析が必要であるう. 考古学の立場から言うと, 関東地方の台地上には, 䋲文時代前期以降, 相当数の遺 跡が残されて扣り，多くの森林が切り開かれてさている ことは事実である、この点からすると，台地上にはかな りの割合で二次林が拡がっていた筈である，とこで報告 者の指摘する植生の変化が, 縄文人たちの森林利用二管 理といら面から見て, ぞの程度のものであったかを是非 ご教示をいただきたい.

次の問題は, ${ }^{14} \mathrm{G}$ 年代で 2,300 年前に当る層準よりイ 
ネの種子と花粉が確認されたといらことであるが，これ は考古学者にとってきわめて重大な問題である. ${ }^{14} \mathrm{C}$ 年 代が登呂遺跡などですバラッキがあり，この年代をただ ちに実年代とすることには確かに問題があろうし，また 弥生文化の関東地方に和ける開始という点からすれば否 定の断が加兄らるものであるう.しかし，ここでは， これらの問題に深くかかわることなく，とりあえずこの 年代が示すような時期にイネの移入があるかどらかの可 能性についてだけ考えてみよう. そこで, 縄文時代終末 期の土器の動きと道具の構成について簡単に跳めてみる ことにしよう.

近年東日本において大洞 $\mathrm{A}$ 式期と, それに続く時期の 資料報告や論文が活発に発表されていることは注目され る.たとえば，中村五郎『幾内第 1 様式に並行する東日 本の土器』, 設楽博已「中部地方に和ける弥生土器の成立 過程」『信濃 34-4』, 吉川国男「西関東に和ける弥生文化 の波及について」『埼玉県史研究 9 』といった 1982 年に 発表された論文は, 東日本に扔汸る弥生時代の開始を, 前期段階に遡らせようとするものであった。こういった 流れは, 当然関東地方に沶ける縄文文化終末の様相をい つまでも特ぼろげにはして括かないだろら，福島県薄磯 貝塚では橿原式土器が発見され, 西日本からの遺物の流 れがさらに先行する時期にもあることが示されたり, 青 森県八戸市では遠賀川式土器が確認されている. 関東地 方に和ける縄文時代の終末期の土器として杉田式, 千網 式, 荒海式, 大洞 $\mathrm{A} \cdot \mathrm{A}^{\prime}$ 式などの土器が知られている が, 今回示された ${ }^{14} \mathrm{C}$ 年代は, 䋲文時代終末期から弥生 文化の波及期にかけての土器の姿を検討するよいきっか けとなったのかも知れない。

群馬県上人見遺跡 -上久保遺跡 -千網谷戸遺跡, 埼玉 県わらび沢遺跡 - 如来堂遺跡 - 白幡中学校遺跡, 神奈川 県平沢同明遺跡 - 三ヶ木遺跡, 千葉県荒海遺跡 - 福島県 岩屋遺跡・薄磯貝塚, 新潟県村宎遺跡などなどの土器群 の再整理が必要となろら。これらの資料は東日本のなか に稲を知っている人，あるいは稲作にかかわる物がモザ イク的に入り込んでいることを示しているとも考觉られ まいか．ひとつの技術体系を持った稲作文化が広まる段 階が弥生中期の段階のものであるとすることがでさるな

\section{1. まえがき}

シンポジウムのポストプリントにコメントせよとの要 請を受けて, 辻ほかの論文「縄文時代以降の植生変化之
ら，「点を結んでいく形」で稲が伝わった時期をとの前に 認めることに私どもはやぶさかではないのである。

次に道具の問題について触れねばならない。この期の 農耕具は関東地方ではもちろん確認されていない. 埼玉 県池上遺跡では須和田期の住居址中からコメが出土し， 宮ノ台期では扁平片刃石爹の出土も多い. 関東地方に拉 いては弥生中期の段階では「完成されて日本に入ってき た稲作文化を支えた道具」が移入されているのである。

ここで考えて扣きたいことは，縄文時代に特ける植物食 をめぐる技術体系が，多くの土腐群に表われた貯藏技術 の発達と磨石・石皿・土器・木製工具・木製容器に示さ れる道具と調理技術の組織化であるとその歴史的意義を 規定できるのに対し，弥生時代の澱粉質食料に関わる技 術体系は，稲作に関わる木製農耕具，その製作のための 工具, 水田, 大形罜形土器や貯蔵施設乞して調理技術之 いったものを有していたのである.

この両者の接点をみると, 九州においては縄文時代晚 期前半に和いては磨石・石皿のセットの增加がみられる のに比し，弥生期に大っては激減している，近畿に扣い ては紫雲出の報告に括いて既に佐原真氏は弥生文化期に 入ると磨石はみられなくなるとしている，それは関東・ 東北においても同様な傾向を示しているのである. 弥生 時代の経済基盤を支えた道具は，基本的に磨石・石血を 含まない形で組織され東へと広がっていったと考えられ るのである.

さてそれでは東日本の大洞 $\mathrm{A}$ 式期以降の, コメの存在 を知っても蛙かしくはない縄文人にとっての労働手段は ぞのようになっていただろらか．現時点では，どちらの 証拠をる残していないとするのが妥当であるが，どちら かといえば縄文的な道具を維持していたというようにも 兒ることができる.一層精緻な研究を進めばならない状 況なのである・

本論文の持つ意義は, 東日本の弥生文化に関する土器 研究とタイムリーにかさなり合って, 考古学者に縄文時 代終末＝弥生時代の開始期についての議論を引き起こす ことになるさっかけとなったのではという点にあると考 える・

（筑波大学歴史人類学系）

$$
\begin{gathered}
\text { 那須 孝 悌 } \\
\text { Takayoshi NASU }
\end{gathered}
$$

農耕」を拝読した. 古植生と古植物相の変化に関する研 究成果, 乱よび貝類採取の捕獲圧の変化について興味樑 い記述に接することができたが，シンポジウムテーマが 
「日本考古学々第四紀研究」であることに鑑みて $2 \cdot 3$ の コメントを試みたいと思う.

\section{2. 層準と年代について}

辻汪かの論文飞和壮る古植物生層序の研究は, 松島義 章氏による詳細な層序学的研究の成果伛もとずいて, そ の上に積み重ねられたものである. 従ってその層序は松 島氏の地質断面図汇試料採取地点を付記したるのとなっ ている.

古生物学的研究を行う場合, 有能な地質学者と共同で 層序を検討するか，さもなければば过注かの論文のよう に詳細な層序がすでに明らかになっている地域を対象と するのはたしかに有効な方法である. しかし，古植生を はじめとする古環境の変化と人間活動との相互関係を論 ずる場合, たと自然科学分野からの検討であっても, 対象とする地層のどの層準に当時の人々の生活面がある かを明らかにしてとりかかる必要がある.とのために は, 近接する遗跡の遗構面や遺物包含層を, 低湿地内の 対象地点に括層理面や地層中にまで追跡する必要が ある. その労力を省くと, 考古学と自然科学が共同して 1 つの課題を論ずるための共通の基盤, すなわち総合化 の柱を失うことになる。

辻添かの論文では, 近くに多くの遺跡があり，乙か も，人間活動が直接的に影響を及注し得る範囲内での低 湿地堆積物を扱っているにもかかわらず，近隣遗跡の遗 構面や遺物包含層がぞの層準に相当するのかを検討して いない，そのため，調查地域に和けるイネの出現と植生 破壊開始の層準を明らかにするといら貴重な成果をあげ ながらも，それが考古学的相対年代区分のどの時代に属 する出来事か明らかにしきれず， ${ }^{14} \mathrm{C}$ 年代を論じたのみ にとぞまっているまた，遺跡（貝塚）の調査から導き 出された捕獲圧の変化と上記の古植物学的成果とが層位 的に（時代的に）どのような関倸にあるか子明らかにし きれていない。

${ }^{14} \mathrm{C}$ 年代はあくまでる，与兄られた試料の ${ }^{14} \mathrm{C}$ 濃度測 定結果をもとに, 半減期という物理化学的定数にもとつ いて計算した值であり，たと兄同一層準の試料であって もその種類や状態などのちがいに応じて異なった数值が 得られるのは周知の事である. 茂吕に据ける $2,160 \pm$ 140 y. B. P. という ${ }^{14} \mathrm{C}$ 年代の 意味するところは, 2,300 年前から 2,020 年前までの間という測定結果(計 算値）が得られたという事であって，この ${ }^{14} \mathrm{C}$ 年代のみ から「直接的な年代値」とか「約 2, 200 年前より古く, お゙括よそ 2,300 年前」と結論づけるのは危険だと思われ る.
いずれにせよ，近い将来において「ヒラー式ボーラ」 を分析用試料の採取だけでなく，地層の追跡にも活用し て，今回の貴重な成果が考古学分野にる直接役立つよ5 に努力されることを切望する。

\section{3. 大型遗体と微小遭体について}

过ほかの論文では $「 250 \mu \mathrm{m}$ 以上のものを大型遣体, これ以下を微小遺体と呼んで，それぞれ同定可能なるの をすべて検討するという新たな手法を試みた」としてい る. 大型と微小との用語上の問題は後述するが，この方 法を「新たな方法」と翌うには問題があり，過去におい ても国内外の研究者によって，実行されてきたことは事 実であろう．筆者も低湿性遺跡の土壤試料中に含まれる 花粉 - 胞子, 微小種実, 大型植物遺体, 珄藻, 木材・木 炭片, 微小炭片, 骨片・貝殼片・昆虫等の動物遺体, 微 小な漛膜・石片 (チップ) ・土器片等の考古遺物などを 共同研究者と共に扱ったことがある（たとえば文部省科 研費特定研「古文化財」昭和 56 年度㐨よび 57 年度年 次報告書).

もともと「大型」と「微小」または“macro-”と “micro-”といら語は, 相対的な大きさの違いを表すだ けの語であるが，古生物学分野に执いては，“macrofossil” は影微鏡の 助けなしで研究するのに十分な大きさ の化石，すなわち肉眼で観察し得る大きさの化石を指 L, “microfossil” 注光学顕微鏡下で観察し得る大きさの 化石を指す．ただし顕花植物の花粉や隐花植物の胞子は 「遺体」とは呼ばないのが通例である。また，花粉分析法 によって得られる花粉, 胞子, 緑藻艺の他の動植物微小 プランクトン，鱗片や毛など植物体の一部などを一括し て呼ぶ場合は palynomorphs（日本語訳はまだ無い）と いら語が用いられる。

辻添かの論文中の記載拉よび考察にあらわれる微小遺 体の実態は，上記の palynomorphs にも相当せず，むし ろシダ植物の小胞子を含む花粉化石群集である.ただし 「約 $250 \mu \mathrm{m}$ 以上のものはすべて大型遺体用とした」こ そによって，花粉粒と共に分離することが可能な巨大花 粉塊やシダ植物の大胞子を, 古花粉学的な同定対象から 除外する結果になっている. 一方，大型遺体とされてい るものは, 光学顕微鏡（実体鏡を含む）や電子顕微鏡を 使用することによって同定が可能になるような微小種実 を含む植物遗体群集であり, 従来の例では笠原安夫氏ら が 2 枚のガーゼを重市あわせて行ってきた研究と注湆同 じ大きさの遗体までを対象としたことになる。

従って方法論的には，大きさにこだわらず，花粉分析 法によって得られる palynomorphs と, セルローズ分解 
処理をほどこさない大型・微小遺体群集とを各々取り扱 い，これらの植物質遺存物以外の情報をもあわせて，層 序を基軸にすえて総合化する，という方法がより良いの ではないかと思われる。

\section{4. あとがき}

関東平野に括ける農耕開始の問題を考える際に, ぞら しても再検討せざるを得ない遺跡に埼玉県碞梘市真福寺 遺跡がある.この低湿性遺跡では 1940 年に甲野勇氏が 低湿地部分を発掘し, 縄文晚期遺物包含層からソバ, リ ョクトウ，ヒョウタンなど（近藤萬太郎氏同定）が出土 したといら。その後再び長谷部言人氏の命により酒詰仲 男・和島誠一両氏が泥炭層を発掘した折にもソバ（中井 猛之進氏同定）などが出土したとの事である.

辻氏らは, 従来, 花粉・胞子を主にあつから微小遺体 $(200 \sim 300 \mu \mathrm{m})$ と，果実を主にあつから大型遺体 $(500$ $\mu \mathrm{m}$ 以上）との間には未検討の間腙があり，見落され勝 ちの遺体があった.

この点を鑑みて，大きさの上で遺体を連続的に分析す るため, 花粉分析用に採集した試料の残りを $250 \mu \mathrm{m}$ を 下限とする大型遺体分析に用いて検討した.

東京湾東岸の村田川流域の茂呂之椎名㱦の 2 地域にあ る縄文海進後の湿地堆積層の各地点で, ヒラー式ボーラ によって採集した柱状試料を $10 \mathrm{~cm}$ 間隔に切り, 各試料 の層準を土塊 $22 \mathrm{~cm}^{3}$ とし，これを $0.25 \mathrm{~mm}$ の篩にか 壮水洗し, 残中の全種実や葉, 茥, 萊などを検討し, ま た，花粉分析試料で $250 \mu \mathrm{m}$ 以上で検出されたものはす べて大型遺体として記述した，表 $2 ， 3$ のようにそれら は $1 \mathrm{~cm}^{3}$ に換算して平均をH（個数 1 以上), $+(0.1-$ $1),-(0.1$ 以下)の 3 段階で表示した.

微小遺体分析では, 縄文時代中期以降を，（1）暖帯落 葉樹林期 (約 4,500-3,500 年前)，（2)照葉樹林期 (約 $3,500-1,900$ 年前)，（3 ) ス丰増加期(約 1,900-1, 500 年前), (4)マツ林期（約 1,500 年前）に4 区別できる とした.（2）照葉樹林の隆盛は中, 南関東を通じて一般 に約 3,500 年前で西日本に比べて $3,000 \sim 4,000$ 年の遅 れは, この森林帯の東・北進速度が気候回復にかかわる ものでなく, 富士火山地帯に起因がある土地条件を強く 受けたとし，なお（3)のスギ増加期は（2)樹林の卓越し た時期内で関東地力に共通しているとみている。(1) 㷊 林期の大形堅果は貝類と共に食料資源に恵みとなった。

そして，(2)の照葉樹林に対して，低湿地を中心とし
一方, 千葉県木更津市苗見作遺跡では, 縄文早期から 晚期までの遺物を産し, 縄文早期前半の撚糸文土器を主 体とする遺物包含層からソバ属花粉が検出されている （パリサーヴェイ株式会社，1980）.

これらのことを考えあわせると, 関東平野において も, 縄文時代, 遅くとす縄文後 ·晚期には畑作作物の栽 培が伝わっていたのではないかと期待される.过ほかの 論文中の資料からは，この期待に応え得るよらな事実を 見出すことはできなかったが，今後の課題として更に検 討を進める必要があると思われる。

末筆ながら，多くの資料と私信をいただいた静岡大学 市原寿文教授に，記して深謝の意を表する.

（大阪市立自然史博物館）

\section{笠 原 安夫 Yasuo Kasahara}

た第 1 の湿地林破壊期があり, 植生に対する人間の著し い干渉の結果ひき抢こされた。このイネの出現開始は ${ }^{14} \mathrm{C}$ 年代に基づけば，約 2,300 年前である.この期は汪 ばハンノキの衰退と一致し，京た，イネ作開始と同時に コナギ, タカサブロウ，オモダカ, イボクサ, イネビエ, ホシクサなどか，和くれてサガミノトリゲモ，シャジク モスブタ盛など水田雑草が出現している（図 5，7）。な お，この図にはアリノトウグサ属（ただし，本州ではこ の属は 1 種なので, 後で述べるアリノトウグサであり, 湿田雑草ならばフサモ属か）がある。

な䅂，イネの出現と共に再びサンショウモ，才オアカ ウキクサ, オモダカ（やや寒地生のサジオモダカ？）な ど茂るが，これらは史前㷌化植物でなく，更新世以前の ものが水田耕作と共に道移入したものとした。また， 第 2 破壊期には氐陵上のマツ属の急増を境として, 低地 の水田耕作の形態にも変化があったと考劣られるこの 破壊は塚田 (1981) がいわれる直接焼畑農耕の集約化に 起因寸るものかどらかは，もっと検討の余地があるとい 亏.

以上によれば， 2,300 年前に始ったイネの耕作は，平 地に始まり，その時期は比較的規模が小さく，1,500 年 前以降の照葉樹林を開いたイネ耕作は，マッ森林期にあ たり，丘陵上のイネ耕作も伴生する雑草群から水稲作と み，同時に低地のイネ作の規模が大きくなったと理解さ れている.

編集委員から本論文についてのコメントの依頼があっ た.ここでは，过氏らが $250 \mu \mathrm{m}$ 以上の大型遺体と名付 けられたものの大部分は, 筆者たちのいら小粒種子に相 
当すると考兑，その $22 \mathrm{~m}^{3}$ のような少量試料での成果 に対して簡単な表示法に魅力がある.さらに一層の成果 を期待する者として若干の提示を行いコメントにかえた w.

花粉や胞子の微小遗体に対して $0.25 \mathrm{~mm}$ 以上のもの は，大型には間違いないが植物遺体で普通大型といえ ば, 筆者は木材, 道具類のようなものと理解している. また，農林種実（種子と小果実）で大粒というのは，普 通は米麦などの長さ $4 \sim 5 \mathrm{~mm}$ 以上のものをいい, ケ シ, アワ粒など 1〜2 $\mathrm{mm}$ の大きさのものは小粒に属す る. 耕地植生を構成する雑草はさらに小粒が多い，たと えば, 筆者 (1976) が, 450 試料 (415 種) の種実で, 大きさを測定したとき長さで $4 \mathrm{~mm}$ 以上は $25(5.5 \%)$ ， $2 \sim 4 \mathrm{~mm} 125(27.7 \%), 1 \sim 2 \mathrm{~mm} 190(42.2 \%), 0.4 \sim$ $1 \mathrm{~mm} 115(25.5 \%)$, それ以下は7 種であった。 そこで 耕地雑草は長さ $0.4 \mathrm{~mm}$ 以上でよい筈だが，しかし，篩 などは長さより幅が基準となるので，篩では辻氏らの $250 \mu \mathrm{m}$ が適当である. 筆者たちは, 金網の上にガーゼ を2, 3 枚重初 $0.4 \mathrm{~mm}$ 以上を兄らび出している.

笠原・武田 (1979) は, 小粒種子分析法として, ビニ ール袋に入っている発掘土 $100 \sim 500 \mathrm{~g}$ をビーカーに入 れ, 水道水で $1 \sim 5$ 日間放置した後に静かに砕く. そし て，前述のよらにガーゼを敷いた杓子状の金網にのせ， 水道水を加減して水洗し，土砂と有㙨物とにわける.土 砂之有機物の分離が難しいものは, 雨方とも径 $9 \mathrm{~cm}$ の シャーレに水と共に入れ，双眼実体影微鏡下で 1 粒づつ ピンセットで拾い出す，後に，(1)標本と比べながら同 定する.しかし，損傷の大きい粒では，(2)走査電子顕 微鏡で撮影し，現生標本のそれと比較して同定する.植 生の復元には一定量の土から何種数類の種子があり, 各 種類別の粒数の算定が重要であり，それによって各地遺 跡の相互比較が可能である.さらに，それを人間とのか かわり合いによる区分，たとえば，作物，食利用植物， 水田, 烟 (人里), 田畑共通種 (晆畩), 野草, 木本などに わけ，とれぞれ表示できれば，遺跡の性格がはっきりし てくる.しかし，光れは大へ儿面倒で時間がかかる. 特 に種類別に摘み出して粒数を数えることである。それで 将来目分量で平均值を $\mathrm{m}$ (100 以上), $\mathrm{W}(10-100), H$ $(1-10),+(1)$, - (1 以下) とするのがよいとも考えて いる.

筆者たちが，最初岡山柿津島の弥生時代の遺跡で，土 $500 \mathrm{~g}$ を 2 回とり分析した. その時は 25 サンプル計 $25 \mathrm{~kg}$ から 131 種・2686 粘を検出した。この場合サン プル土量は適量と考觉たが, 熊本県秋永遺跡の弥生後期
$500 \mathrm{~g} 2$ 回分析で, 55 種 4490 粒, 平安時代 $500 \mathrm{~g} 1$ 回で 41 種 8,226 粒の時は全く扮手上げで, 分析粒を 水中で保存のまま, ようやく 3 年後に算定できた䇢い経 験がある、今では, $100 \mathrm{~g}$ ずつ 2 回，または $200 \mathrm{~g}$ を 1 回で調查を打切っている.

人里植物と耕地雑草とは, 人間の周囲には, 育ての作 物の添が，まねかないで押しかけてくる耕地の雑草と 住居地の人里植物の 2 大群がある. そ机らはひとりで生 完るが人間がつくった環境しか育たないので半自然(生) 的でも岁る。筆者 (1959) が当時調べた田畑雑草は 417 種で，らち古代にはない新㴆化植物が 51 種含まれてい た. 現在は新帰化植物が 120 種ぐらい田畑・畔畔汒侵 入しているので $450 \sim 500$ 種とならている. 人里植物に は畑地の両方にまたがって生えるものがある.

筆者は, 1968 年から今日まで各地 30 余遺跡をしら ベ, 20 余遺跡から中世以前の古代種実 206 種を分析同 定した．うち，古代雑草種類は 160 種であり，原産地別 では東アジア自生種が 60 種（日本が大陸と連なってい た当時から生兄ていたもの), 中国の中南部から東南ア ジア,インドなどの原産とみられるるの 65 種, ヨーロ ッパ，コーラシア，旧世界での広沉種 22 などは史前帰 化植物 (考古学植物) と考觉られた. 雑草では烟雑草 (人 里植物を含呈引) が最多で 81 種, 水田雑草 42 種, 田畑 共通種（甠畔雑草）が 29 種であった. 多年生の睛畔雑 草と 10 余種みられた食利用植物には東アジア自生種が 多かった。

ここには唐津市菜畑遺跡の縄文晚期後半 (山の寺) から 琴耕作土まで, 津島遺跡では弥生前期から明治末年まで $2,300 \sim 2,600$ 年間 も水田遺構がつづいていた. 两遺跡 の出土種実(表省略) と辻氏らの東京海東地点の遺物の種 類を比較してみる. 菜畑遺跡層準の 1 サンプル 100〜 $200 \mathrm{~g}$ を供試し, 全体で $6.5 \mathrm{~kg}$ から 44 科 94 種, 14,559 椟が検出された. 種数で法津島の 128 種に次い で多く, 3 位の福岡市四箇の縄文後期の 88 種を上迴っ ている. $1 \mathrm{~kg}$ 換算粒数 2,240 粒は熊本市秋永, 高崎市 日高遺跡についで多い。これは, 上層が湿田状態で下層 まで水分が多く種実の保存がよい。一方, 津島遺跡では 弥生前期を除さ, 水田は乾田のためと多種の烟作物, 畑 雑草の出土が加わり, 種は多いが, $1 \mathrm{~kg}$ 当り粒数は菜畑 の $1 / 20$ であった. 菜畑で特筆できるのはアリノトウグ サの多数出土と, 山の寺層と板付 1 式層からイネのほか にアワの炭化粒, 括よび, 筆者らが採取土の後に発掘者 中島氏が，山の寺層で麦・豆の炭化粒として採取された むのが，ゴボ，エゴノキ，アズキと末炭化の雑草メロ 
ンであったとれらは，すべて双眼実体顕微鏡では見わ けかながついので，出土粒と現生種子とを走査電子顕微 鏡像で比較してはじめて同定でき得た.

（1）辻氏らの図表の種類と (2)菜畑，（3)津島（表省 略）の出土種を比べてみるに，(1)では作物はイネ 1 種 だが，（2）は 4 種が，(3)はさらに6 種の畑作物が加わ る. 3 遺跡とも出土する水田雑草は, 現生と同じ, コナ ギ, オモダカ, タカサブロウ, イボクサ, ボントクタ デ, ツユクサ, イヌビェ,トリゲモ, シャジクモ, スブ タ, ミゾソバ, カヤツリグサ属, カラムシ属, ギシギン 属, オトギリソウ属などがある. 筆者は本年 4 月中旬に 雲南省南端の景洪の水田主要雑草を見たが, 日本の雑草 とよく似ているのに驚いた。たとえば，前述 15 属種の らち 10 属種があった. 同地方はアジア稲の原郷といわ れるが, 主要雑草も生た原郷と考えられる（8月9日, 日本作物学会中国支部会で発表).

菜畑縄文晚期層では粐殼と少数のコナギ, タガラシが あるが，津島で多かったカタバミ，イヌホオズキ，スべ リヒユ，ハコベ，タネツケバナ，ノミノフスマなど畑雑 草が多く，その直下とまた粐殼の出ない同層からは焼け たアリノトウグサの抽びただしい種実が出土した。これ は雑草の仲間に入らない山草で, 東南アジア方面からツ バメに運ばれ渡来したと考えられている．日当りのよい 山野とくに山ろくの湿地に小さい塔がもらがったように 群生する．この出土の謎ときはむずかしい，焼畑とか火
耕水飡に関係があるのか，この時代のイネは水稲よりも 水陸末分化稲が雑殼と共に導入され，水利のよいアリ， トウグサが生える所には，水稲的に栽培され，他では雑 殼と共に陸稲的な栽培があったのか，そして弥生前期初 頭（夜臼式と板付 I の混層）では，板付遺跡夜臼期と同 様に水田雑草の増加からみても典型的水稲作と考兄られ た。

東京湾東辺でイネ開始が 2,300 年とすると, それは 岡山市津島と同時代であり，北九州から 100４00 年の 間に東上したことになる。また他で見られず菜畑で見ら れたアリノトウグサがイネ開始の直前から出土している のも興味がある.

\section{引用交献}

笠原安夫 (1959) 本邦雑草の種類および地理的分布の研 究 (第 5 報) 日本の耕地雑草の原産地および来歴と海 外に打分布. 農学研究, 47, p. 123-140, 岡山 大学農業生物研究所.

笠原安夫 (1976) 走查電子顕微鏡で見た雑草種実の造形, 130 p., 盖賢堂.

笠原安夫 - 武田満子 (1979) 岡山県津島遺跡の出土種実 の種類同定の研究一日本各地遺跡間の残存種実の比較 とそれらから見た農耕の伝播と形態の推定一. 農学研 究, $58(3,4)$, p. 117-179, 岡山大学農業生物研究 所.

塚田松雄（1981）過去一万二千年間一日本の植生変遷史 II. 新しい花粉帯. 日本生態学会誌，31， p. 201215 .

(財)大原奖農会)

\section{論評に対する原著者の回答}

\section{Author's Replies to the Comments}

过誠一郎・南木睦彦・小池裕子 Seiichiro Tsujı, Mutsuhiko Minam and Hiroko Korke

表記の小論に対し有意義な御意見や資料を怙寄せいた だいた加藤晋平・山田昌久, 那須孝悌, 笠原安夫, 中村 純，藤原宏志の各氏に感謝いたします。

御指摘のあったすべての項目について扣答えする紙面 は許されないので，ここでは主要な問題を取り上げて述 べさせていただきたくことを，あらかじめ御諒承願いた い.な拉，返答に入る前に，村田川流域の茂呂の沢に拈 けるその後の調查によって得られた成果の概要を述べて 技きたい，それらは後述の返答の内容に大なり小なりか かわりをもつものである.

\section{1. その後の成果}

その後の調查は, 茂呂の沢の SK-37 の上流約 $500 \mathrm{~m}$ の一帯で行った. 径 $6 \mathrm{~cm}$ のシンウオール・サンプラー
による試掘とピット掘り（約 $2 \mathrm{~m} \times 2 \mathrm{~m}$ ) による地質層 序, 遺物, 遺構面の検討が主なものである.

もっとも詳細に検討のできたピット SK-46 では, 360 $\mathrm{cm}$ 下まで深掘りでき, 盛土を除くと 17 層（上位より 第 1 層から第 17 層) が区分された（図 1 ). 第 $13 \mathrm{~b}$ 層 は茂吕火山灰である。これは薄層ながらも連続性がきわ めてよく有効な鍵層である. 第 10 層には古墳時代後期 の土器片や, 木製品をともなら木組みの遺構が確認され た. 第 7 層下面にも土器片が比較的多く散在し, 土䁃学 的に当時の生活面となった可能性が指摘された。第 5 層 は宝永スコリア (1707 年降灰)である.これは人の足跡 の中に特に厚く堆積して和り，当時の水田面が降灰によ ってそのま保存されているようである。 